\title{
Survival of Epidemic, Clinical, Faecal and Recreational Beach Enterococci Strains with Putative Virulence Genes in Marine and Fresh Waters
}

\author{
Asmat Ahmad1, Ayokunle Christopher Dada1, Gires Usup² \\ ${ }^{1}$ School of Biosciences and Biotechnology, Universiti Kebangsaan Malaysia, Bangi, Malaysia \\ ${ }^{2}$ School of Environmental \& Natural Resource Sciences, Faculty of Science \& Technology, Universiti Kebangsaan \\ Malaysia, Bangi, Malaysia \\ Email: asmat@ukm.my
}

Received 11 October 2013; revised 13 November 2013; accepted 5 December 2013

Copyright (C) 2014 by authors and Scientific Research Publishing Inc.

This work is licensed under the Creative Commons Attribution International License (CC BY). http://creativecommons.org/licenses/by/4.0/

(c) (i) Open Access

\begin{abstract}
Culturable faecal coliform, epidemic, clinical, faecal and recreational beach enterococci strains possessing putative virulence genes were enumerated over the course of 5 weeks to comparatively assess their persistence in tropical marine and fresh waters. For the clinical and epidemic strains tested, it took $2.38 \pm 0.45$ days for a $1-\log$ reduction $\left(T_{90}\right)$ in marine water. A higher $T_{90}$ average of $2.51 \pm 0.08$ was observed for the commensal and environmental strains. Generally, lower $T_{90}$ values of $2.14 \pm 0.26$ and $2.15 \pm 0.16$ days respectively were observed for hospital and community acquired enterococci strains in fresh water mesocosms subjected to tropical ambient temperature. Beach water enterococci and enterococci recovered from faeces of humans survived for up to 20 days and 23 days respectively in fresh and marine waters. The epidemic strain, MMH594, an esp-positive clinical bacteremia isolate that previously caused multiple infections in a hospital ward outbreak fares favourably well in tropical marine and fresh aquatic environments. For enterococci, the decay rate was approximately $13 \%$ higher in fresh water than was observed for marine water. On the contrary, for $E$. coli, the decay rate was approximately $17 \%$ lower in fresh water than was observed in marine water. Generally, the whole, the population trends of $E$. coli and enterococci in fresh and marine water mesocosms did not reveal any evidence of growth. Our findings suggest that potentially pathogenic bacteria can resume active growth after three weeks of being harboured by the reservoir-beach sand and still pose threat to public health.
\end{abstract}

\section{Keywords}

Clinical Enterococci Die-Off, Beach Enterococci Die-Off, Faecal Enterococci Die-Off, Tropical Water

How to cite this paper: Ahmad, A., C. Dada, A. and Usup, G. (2014) Survival of Epidemic, Clinical, Faecal and Recreational Beach Enterococci Strains with Putative Virulence Genes in Marine and Fresh Waters. Journal of Environmental Protection, 5, 482-492. http://dx.doi.org/10.4236/jep.2014.56051 


\section{Introduction}

Microbial contamination of water resources remains a key problem in many parts of the world. Untreated or only partly treated wastewaters and wastes are frequently released into rivers and sea, which affect surface water quality [1]. Traditionally, the presence of indicator organisms in water is used to decipher if the water has been contaminated by faecal material; implying the potential presence of pathogens [2] [3]. The use of Escherichia coli and members of the genus Enterococcus, the enterococci (ENT) have been recommended for the assessment of hygienic safety of recreational waters [1] [4] [5]. Nonetheless, the choice of which particular indicator to utilize in monitoring recreational water bodies has been a source of considerable debate among the public health officials [6]. One striking point in these debates is the ability of indicator organisms to grow in the environment, a decisive factor which questions their position as indicator organisms. A number of studies have been conducted on the survival of indicator organisms in the environment but are mainly restricted to temperate and subtropical settings. There is a paucity of published information for such studies in tropical settings.

Apart from being indicator organisms, enterococci also cause diseases [7]. The severity of these diseases is mediated by the presence of one or more virulence markers previously described. Among these are gelatinase, enterococcal surface protein (Esp), aggregation substance (asa), cytolysin (cyl) and hyaluronidase (hyl) [7]-[9]. Although only few studies have focused on pathogenicity of environmental strains, there seems to be a general consensus that clinical strains are more pathogenic than their clinical counterparts. Given the permeable barriers in waste handling, generation and transport in the environment of developing nations as argued by Dada et al. [10], there is the need to know the fate of pathogenic strains of enterococci should they find their way into the environment. To the best of our knowledge, there is currently no published information on a comparative assessment of the survival of epidemic and environmental strains of enterococci in fresh and marine water at a temperature of $29^{\circ} \mathrm{C} \pm 1{ }^{\circ} \mathrm{C}$ which is common at tropical beaches all year round. The examination of the comparative survival of epidemic and environmental strains of these organisms in recreational beach environment is important for an accurate exposure assessment and risk characterization of potentially pathogenic enterococci. The current study thus aims to assess the persistence of culturable faecal coliform vs. epidemic, clinical, faecal and recreational beach enterococci strains possessing putative virulence genes over the course of 5 weeks in tropical marine and fresh waters.

\section{Materials and Method}

\subsection{Description of Clinical, Faecal and Recreational Beach Enterococci Strains}

Eight strains of enterococci were examined in this study. These included clinical strains isolated from catheters of hospital patients with urinary tract infections in $2012(n=2)$, strains recovered from faecal samples $(n=2)$, strains carrying virulence genes recovered from recreational beach water $(n=2)$, a strain that previously caused hospital wide epidemic $(n=1)$ and a vancomycin resistant strain. Phenotypic confirmation of isolates was done following previously published guides [11] [12]. Isolates were tested to confirm if they hydrolyse bile esculin and grow in $6.5 \% \mathrm{NaCl}$ and in brain heart infusion agar (BHIA) at $45^{\circ} \mathrm{C}$. Other tests were to determine motility on SIM agar (Oxoid, UK) and fermentation of a 1\% concentration of mannitol, sorbitol, arabinose, raffinose, sucrose, lactose and inulin.

Identities of selected isolates were also confirmed using ddl gene sequencing as described by Dutka-Malen et al. [13]. Sequencing was performed with an ABI 3130XL 20 genetic analyzer (Applied Biosystems). Polymerase chain reaction (PCR) assays were applied to check for the presence of virulence determinants: aggregation substance (asa), cytolysin (cylA), enterococcal surface protein (esp), gelatinase (gelE) [14]. Details of primers are listed in Table 1. Multiplex PCR conditions used in this study included an initial activation step at $95^{\circ} \mathrm{C}$ for 4 mins followed by 30 cycles of denaturation at $94^{\circ} \mathrm{C}$ for $1 \mathrm{~min}$, annealing at $55^{\circ} \mathrm{C}$ for $1 \mathrm{~min}$, extension at $72^{\circ} \mathrm{C}$ for $1 \mathrm{~min}$ and a single cycle of 7 mins at $72^{\circ} \mathrm{C}$. PCR products were checked using $1 \%$ agarose gel electrophoresis.

\subsection{Marine and Fresh Water Mesocosm Preparation}

Marine and fresh water samples were collected in sterile 5-L polypropylene containers from two marine beaches 
Table 1. Primers used during the study.

\begin{tabular}{|c|c|c|c|}
\hline Gene & Primer name & Sequence (5'-3’) & Product (bp) \\
\hline \multirow[t]{2}{*}{ D-alanine:D-alanine ligase (ddl) } & ddlF & ATCAAGTACAGTTAGTCTT & 941 \\
\hline & ddlR & ACGATTCAAAGCTAACTG & \\
\hline RAPD Primer & D8635 & GAG CGG CCA AAG GGA GCA GAC & \\
\hline \multirow[t]{2}{*}{ Aggregation substance (asa + ) } & ASA 11 & GCACGCTATTACGAACTATGA & 375 \\
\hline & ASA 12 & TAAGAAAGAACATCACCACGA & \\
\hline \multirow[t]{2}{*}{ Gelatinase (gel+) } & GEL 11 & TATGACAATGCTTTTTGGGAT & 213 \\
\hline & GEL 12 & AGATGCACCCGAAATAATATA & \\
\hline \multirow[t]{2}{*}{ Cytolysin (cyl+) } & CYT I & ACTCGGGGATTGATAGGC & 688 \\
\hline & CYT IIb & GCTGCTAAAGCTGCGCTT & \\
\hline \multirow[t]{2}{*}{ Enterococcal surface protein $\left(\mathrm{esp}^{+}\right)$} & ESP $14 \mathrm{~F}$ & AGATTTCATCTTTGATTCTTGG & 510 \\
\hline & ESP $12 R$ & AATTGATTCTTTAGCATCTGG & \\
\hline
\end{tabular}

in Malaysia. Fresh water samples were collected from rivers that drain into the receiving marine waters. Pooled samples of the fresh and marine water were sterilised by autoclaving. Quality assurance tests to determine the effectiveness of the sterilization was by way of sterility tests by culturing $5 \mathrm{ml}$ water of each water sample in Brain Heart Infusion (BHI) agar (Oxoid, UK) and incubated at $37^{\circ} \mathrm{C}$ for $48 \mathrm{~h}$. One hundred microlitres portion of these tubes were subsequently plated on Columbia Blood Agar (Oxoid CM0331) supplemented with 5\% (v/v) sheep blood an incubated for $24 \mathrm{~h}$ at $37^{\circ} \mathrm{C}$. Measurements for dissolved oxygen, $\mathrm{pH}$, salinity and temperature of the water samples were taken using YSI model 600QS (YSI, Yellow Springs). The pooled fresh water had a salinity of $0.31 \mathrm{ppt}$ and $\mathrm{pH}$ of 7.39 and the pooled marine water had a salinity of $28.53 \mathrm{ppt}$ and $\mathrm{pH} 7.41$.

\subsection{Fresh and Marine Water Inoculation}

Overnight cultures from Brain Heart Infusion (BHI) agar (Oxoid, UK) supplemented with 5\% sterile sheep blood for each strain. These were added to the sterile marine and fresh water such that the initial concentration was approximately $10^{7} \mathrm{cfu} / \mathrm{ml}$ of each water sample. One kilogram of autoclaved soil was weighed into a sterile plastic bag and added to each of three mesocosms with stirring. In each case, vigorous stirring was employed to ensure even distribution of the inoculum. All samples (marine and fresh water microcosms) were kept for an incubation period of 5 weeks in the dark at ambient temperatures $\left(28^{\circ} \mathrm{C} \pm 2^{\circ} \mathrm{C}\right)$ in the dark. Mesocosms were sampled within 15 mins after inoculation $(\mathrm{DO}, \mathrm{t}=0)$. The sediment was minimally disturbed during sampling to avoid artificially elevated enterococci concentrations in the water column. Mesocosms were sampled in triplicates daily in the first week and on alternate daily intervals in the second week up to and including 18 days duration. This involved aseptic plating of each water microcosm on Brain Heart Infusion agar and subsequent incubation at $35^{\circ} \mathrm{C}$ for 24 hours. Quality assurance tests to determine the sterility of the plates included the use of dry BHI agar plates, representatives (10\%) of each batch were incubated without incubation at $35^{\circ} \mathrm{C}$ for 24 hours and at ambient temperature for 3days. This period was sufficient to allow growth of any fungal or bacterial contaminant on the plate.

\subsection{RAPD-PCR Typing}

D8635 primer was used for the RAPD-PCR reaction. DNA extraction was achieved by repeated washing, harvesting and resuspension of cells in sterile TE buffer before subsequent boiling in TE buffer for 10 mins at $95^{\circ} \mathrm{C}$. PCR amplifications were performed in $0.2 \mathrm{ml}$ reaction tubes each with $25 \mu \mathrm{l}$ of mixtures composed of $1 \mathrm{uM}$ of primer D8635, $200 \mu \mathrm{M}$ of dNTPs, $1 \times$ of PCR Buffer, $2.5 \mathrm{mM}$ of $\mathrm{MgCl}_{2}$, 2U of Taq polymerase and $1 \mu \mathrm{l}$ of extracted solution of enterococcal DNA. PCR condition adopted involved an initial cycle of $94^{\circ} \mathrm{C}$ for 2 min; 35 cycles of $94^{\circ} \mathrm{C}$ for $1 \mathrm{~min}$, annealing at $46.9^{\circ} \mathrm{C}$ for $1 \mathrm{~min}, 72^{\circ} \mathrm{C}$ for $1.5 \mathrm{~min}$ and a final extension step of $72^{\circ} \mathrm{C}$ for 
10 min. A 10ul volume of each PCR product was mixed with $2 \mu \mathrm{l}$ of loading dye and subjected to a $1 \%$ TAE buffer electrophoresis system. In each run, a molecular weight marker (1 kb PCR ladder, Invitrogen) was included. Following photography using a UV transilluminator, images were processes using ImageJ and Phython PyElPh version 2.6.5.

\subsection{Determination of Virulence Markers Distribution in Enterococci}

Polymerase chain reaction (PCR) assays were applied targeting the virulence determinants aggregation substance (asa), cytolysin (cylA), enterococcal surface protein (esp), gelatinase (gelE) [14]. Details of primers are listed in Table 1. Multiplex PCR conditions used in this study included an initial activation step at $95^{\circ} \mathrm{C}$ for 4 mins followed by 30 cycles of denaturation at $94^{\circ} \mathrm{C}$ for $1 \mathrm{~min}$, annealing at $55^{\circ} \mathrm{C}$ for $1 \mathrm{~min}$, extension at $72^{\circ} \mathrm{C}$ for $1 \mathrm{~min}$ and a single cycle of $7 \mathrm{mins}$ at $72^{\circ} \mathrm{C}$. PCR amplicons of asa, cylA, esp, gelE from the separate recovered strains were confirmed by DNA sequencing with an ABI 3130XL 20 genetic analyzer (Applied Biosystems). The DNA sequences were blasted for sequence similarity to annotated sequences at http://www.ncbi.nlm.nih.gov.

\subsection{Resuscitation Experiments}

Following an observation of CFU/ml values of enterococcal counts lower than 0.1 for any of the mesocsms, resuscitation experiments was carried out after 5weeks. As described by leo et al. [15], ten 1-ml of each 10-fold dilution of microcosm were placed in $9 \mathrm{ml}$ of TSB medium and the suspensions incubated at volumes of undiluted microcosm and ten 1-ml volumes room temperature for five days. All cultures in which visible turbidity appeared, were spread onto S\&B agar and colonies subsequently confirmed to detect any possible contaminant. All culture tubes with visible growth were scored and a probability table [16] was used to calculate the MPN. For all mesocosms that was subjected to resuscitation experiments, sand samples were also analysed to check if occurrence of VBNC bacteria were substrate dependent (beach sand) or existed largely unbound but suspended in the water column. Sediment samples were processed by adding $10 \mathrm{~g}$ (wet weight) of sediment to $100 \mathrm{ml}$ of buffered water followed by sonication of the mixture for $30 \mathrm{~s}$ at $200 \mathrm{rev} / \mathrm{s}$. The sample was then allowed to settle for 10 min before subjecting the supernatant to membrane filtration.

\subsection{Decay Rate Calculations}

Decay rates of culturable enterococci concentrations were calculated as described by Anderson et al. (2005) using the standard exponential growth/decline equation (Equation (1)):

$$
r=\left[\operatorname{In}\left(N_{t}\right)-\operatorname{In}\left(N_{o}\right)\right] / t
$$

where $\boldsymbol{r}=$ decay rate, $\boldsymbol{N}_{\boldsymbol{t}}=\log _{10}\left(\mathrm{CFU} 100 \mathrm{ml}^{-1}\right)$ at time $\boldsymbol{t}, \boldsymbol{N}_{0}=\log _{10}\left(\mathrm{CFU} 100 \mathrm{ml}^{-1}\right)$ at time zero, and $\boldsymbol{t}=$ time (in days). Time $(\boldsymbol{t})$ was determined by the days between the first sampling event and either the last sampling event or when culturable cells could no longer be detected. On the whole, a negative $\boldsymbol{r}$ depicts a decrease in CFU (net cell die off), while a positive $\boldsymbol{r}$ connotes an increase in CFU (growth). An absolute value of the decay rate was taken as the magnitude of change in culturable concentrations.

\subsection{Statistical Analysis}

For each microcosm, the average log-transformed spread plate counts were analyzed by linear regression to calculate the time elapse for a 1-log removal $\left(T_{90}\right)$. Multivariate linear regressions was used to model the significance of association between water type (marine vs fresh), isolate type (enterococcus vs $E$. coli) and strain classification (environmental vs. clinical) on survival using Stata (Stata Corp. USA). P $<0.05$ was considered statistically significant.

\section{Results and Discussion}

Culturable faecal coliform (FC), epidemic, clinical, faecal and recreational beach enterococci strains possessing putative virulence genes (Table 2) were enumerated over the course of 5 weeks to comparatively assess their persistence in tropical marine and fresh waters. The intentional addition of epidemic and potentially virulent 
Table 2. Description of Strains used for Mesocosm inoculation.

\begin{tabular}{|c|c|c|c|c|c|c|c|}
\hline \multirow{2}{*}{ Organism } & \multirow{2}{*}{ Strain } & \multirow{2}{*}{ Collection date } & \multirow{2}{*}{ Source } & \multicolumn{4}{|c|}{ Enterococci virulence marker } \\
\hline & & & & esp & asa & gel & cyl \\
\hline \multicolumn{8}{|l|}{ Pathogenic } \\
\hline E. faecalis & MMH594 & $1999^{*}$ & Clinical & + & + & + & + \\
\hline E. faecalis & VRBW23 & 2013 & Clinical & + & + & + & + \\
\hline E. faecalis & UT27 & 2013 & Urinary catheter & + & + & + & + \\
\hline E. faecalis & UT44 & 2013 & Urinary catheter & - & + & + & + \\
\hline \multicolumn{8}{|l|}{ Commensal } \\
\hline E. faecalis & FA7 & 2013 & Human faeces & + & - & + & - \\
\hline E. faecalis & FA12 & 2013 & Human faeces & + & - & + & - \\
\hline E. faecalis & BWE16 & 2013 & Marine beach water & + & + & + & - \\
\hline E. faecalis & BWE24 & 2013 & Marine beach water & + & - & + & - \\
\hline E. coli & FAE12 & 2013 & Human faeces & NA & NA & NA & NA \\
\hline
\end{tabular}

NA: not applicable; ${ }^{*}$ although collected as laboratory stock culture in 2013.

strains to natural waters could pose considerable risks to human health. Additionally, assessment of differential survival of these strains would present considerable challenges especially with continued diffuse source inputs of indicator organisms. For these reasons, the study was conducted using a mesocosm setting.

All tested $E$. faecalis isolates were confirmed by ddl gene sequencing (Figure 1). All the mesocosms were inoculated with exponentially grown enterococci cells at a final concentration of $10^{7} \mathrm{cfu} / \mathrm{ml}$. This was in line with previously reported published information that starved and stationary cells have superior survival abilities and multi-stress resistance compared to growing cells [17]. The RAPD fingerprint of the enterococci strains by the second week up to the $23^{\text {rd }}$ day had disappeared with only a maximum of two bands remaining. This was in concert with Liu et al. [18]. However, morphological features, detection of ddl and virulence gene carriage of the enterococci strains didn't change up till the $23^{\text {rd }}$ day of storage. Repeated subculturing or long-term storage has been documented to cause significant variations in PFGE profiles of the strains, but the variations does not invalidate epidemiological lineage of the tested strains [19].

Figure 2 presents the survival pattern of a total of eight strains of enterococci and a strain of faecal E. coli over a period of 23 days in fresh and marine water. For the clinical and epidemic strains tested, it took $2.38 \pm$ 0.45 days for a 1-log reduction $\left(T_{90}\right)$ in marine water. A higher $T_{90}$ average of $2.51 \pm 0.08$ was observed for the commensal and environmental strains. It is difficult to make comparisons of the $\mathrm{T}_{90}$ obtained as there is a dearth of published information on the survival of pathogenic enterococci in tropical fresh or marine waters. Lleo et al. [15] reported survival of a single clinical strain of E. faecalis 56R but did not highlight the $\mathrm{T}_{90}$ value for the tested strain. In line with other survival studies however, the reduction rate in the absence of light followed the first order kinetics $(y=m x+b)$ [20] [21]. Generally, lower $T_{90}$ values of $2.14 \pm 0.26$ and $2.15 \pm 0.16$ days respectively were observed for hospital and community acquired enterococci strains in fresh water mesocosms subjected to tropical ambient temperature in our study.

Beach water enterococci and enterococci recovered from faeces of humans survived for up to 20 days and 23 days respectively in fresh and marine waters (Figure 2(c) and Figure 2(d)). Comparing cell counts for day 1, E. coli isolated from human faeces survived longer in fresh water than in marine water. Also, clinical strains isolated from urinary tract infection patients (UT1 and UT44) could no longer be cultured at days 17 and day 20 respectively when inoculated into fresh and marine waters (Figure 2(a)). The epidemic (MMH594) and the vancomycin resistant (VRBW23) strains were no longer culturable at 20 days when inoculated in fresh and marine waters (Figure 2(b)). The similar number of days of survival as was observed for environmental strains tested suggest that the epidemic strain, MMH594, an esp-positive clinical bacteremia isolate that previously caused multiple infections in a hospital ward outbreak [22] fares favourably well in marine and fresh aquatic environments in tropical settings. 
Presented in Table 3 is the correlation coefficient $\left(\mathrm{R}^{2}\right)$ and die off rate for all tested strains of enterococci. For enterococci, the decay rate was approximately $13 \%$ higher in fresh water than was observed for marine water. On the contrary, for E. coli, the decay rate was approximately $17 \%$ lower in fresh water than was observed in marine water. The observation of higher decay rate of $E$. coli in marine water as opposed to the comparatively lower decay rate of enterococci in marine water is in agreement with previous studies [23].

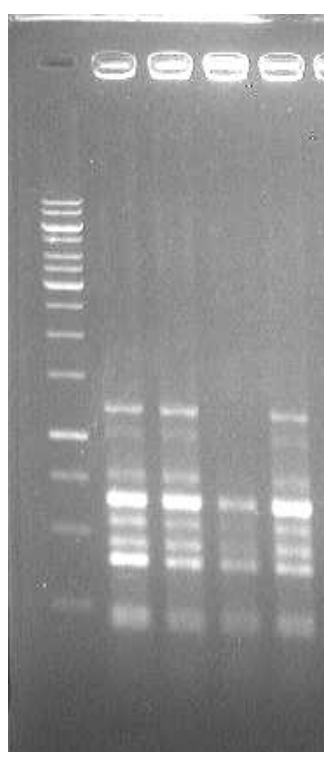

(a)

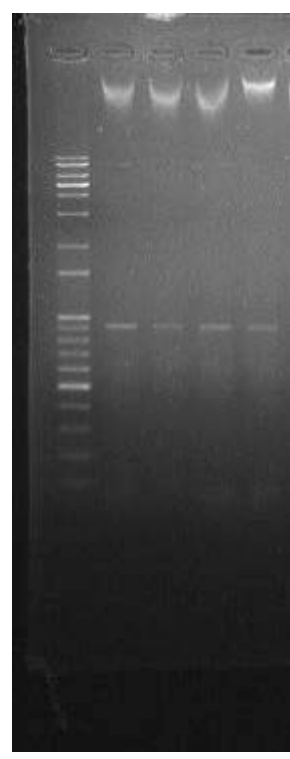

(b)

Figure 1. Panel (a) Molecular typing of an isolate from each group of E. faecalis by RAPD-PCR. Reference: Gel $1 \%$ agarose in buffer TAE $1 X$ buffer. Panel (b) Identification of $E$. faecalis using ddl gene (900 bp). Reference: Gel 1\% agarose in buffer TAE 1X buffer. Panel (a) and (b) Lane 1: 1 kb DNA ladder, Lane 2: E. faecalis FAE7, Lane 3: E. faecalis BWE24, Lane 4: E. faecalis UTI44 and Lane 4: E. faecalis UTI44 and UTI27.

Table 3. Regression results, die off rate and T90 removal time for the tested enterococci and E. coli strains in fresh and marine water at tropical temperature condition.

\begin{tabular}{|c|c|c|c|c|c|c|c|}
\hline \multirow{2}{*}{ Isolate } & \multicolumn{4}{|c|}{ Marine water } & \multicolumn{3}{|c|}{ Fresh water } \\
\hline & Temp $\left({ }^{\circ} \mathrm{C}\right)$ & $\mathrm{R}^{2}$ & $\mathrm{~T}_{90}$ (days) & $\mathrm{k}\left(\right.$ day $\left.^{-1}\right)$ & $\mathrm{R}^{2}$ & $\mathrm{~T}_{90}$ (days) & $\mathrm{k}\left(\right.$ day $\left.^{-1}\right)$ \\
\hline MMH594 & 29.5 & 0.83 & 1.88 & 0.53 & 0.62 & 2.13 & 0.47 \\
\hline VRBW23 & 29.5 & 0.69 & 2.41 & 0.41 & 0.49 & 2.49 & 0.40 \\
\hline UT27 & 29.5 & 0.71 & 2.97 & 0.34 & 0.89 & 1.87 & 0.53 \\
\hline UT44 & 29.5 & 0.78 & 2.25 & 0.44 & 0.87 & 2.07 & 0.48 \\
\hline $\mathrm{T}_{90}$ Average $+\mathrm{SD}$ & & \multicolumn{3}{|c|}{$2.38 \pm 0.45$} & \multicolumn{3}{|c|}{$2.14 \pm 0.26$} \\
\hline FA7 & 29.5 & 0.83 & 2.55 & 0.39 & 0.79 & 2.12 & 0.47 \\
\hline FA12 & 29.5 & 0.78 & 2.59 & 0.39 & 0.69 & 2.01 & 0.50 \\
\hline BWE16 & 29.5 & 0.80 & 2.51 & 0.40 & 0.62 & 2.09 & 0.48 \\
\hline BWE24 & 29.5 & 0.79 & 2.40 & 0.42 & 0.68 & 2.38 & 0.42 \\
\hline $\mathrm{T}_{90}$ Average $+\mathrm{SD}$ & \multicolumn{4}{|c|}{$2.51 \pm 0.08$} & \multicolumn{3}{|c|}{$2.15 \pm 0.16$} \\
\hline E. coli FAE12 & 29.5 & 0.91 & 2.14 & 0.47 & 0.64 & 2.58 & 0.39 \\
\hline
\end{tabular}

R2—regression correlation coefficient, $\mathrm{T}_{90}$ is the time needed or 1-log reduction, $\mathrm{k}$-die off rate. 


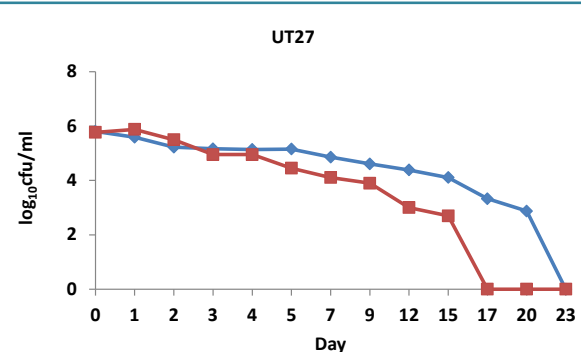

MMH594

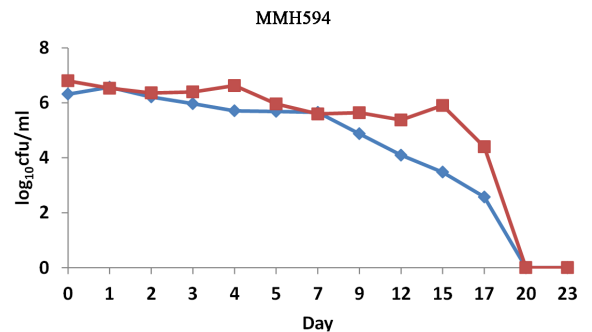

BWE16



FAE7

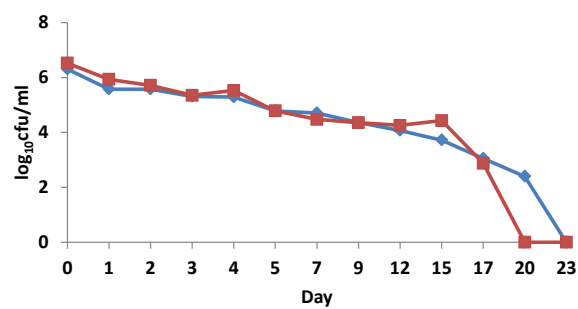

E.coli FAE12

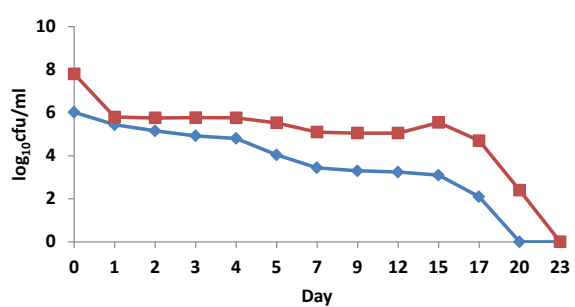

UT44

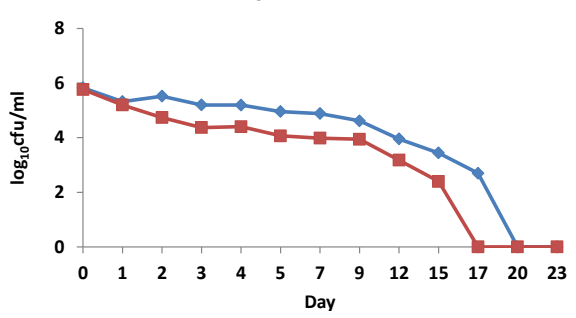

(a)

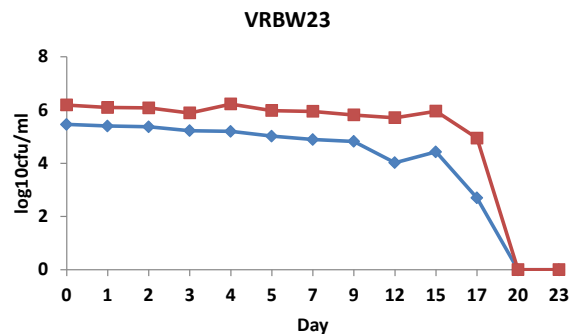

(b)

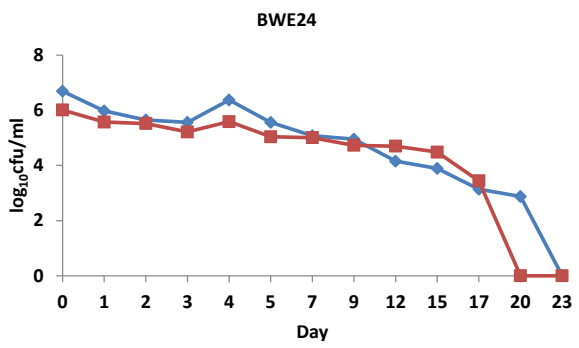

(c)

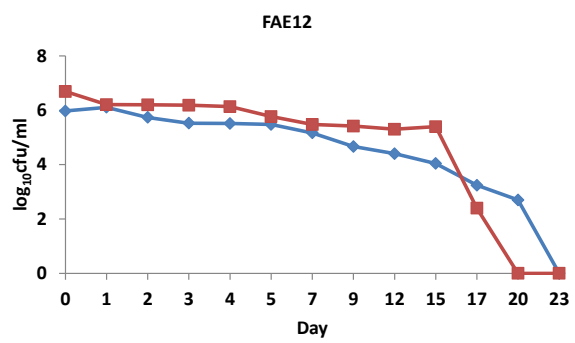

(d)

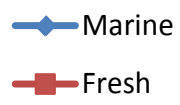

(e)

Figure 2. (a) Survival of enterococci isolates recovered from urinary tract infections in marine and fresh water at 29 C; (b) Survival of epidemic and vancomycin resistant enterococci isolates in marine and fresh water at 29 C; (c) Survival of recreational beach water enterococci isolates in marine and fresh water at 29 C; (d) Survival of enterococci isolates recovered from human faeces in marine and fresh water at $29 \mathrm{C}$; (e) Survival of $E$. coil isolate recovered from human faeces in marine and fresh water at $29 \mathrm{C}$. Spread plate counts obtained for each time point days were averaged and log-transformed. A linear regression was calculated for each of the mcrocosms to assess the time sufficient to achieve a 1-log reduction. 
A multivariable linear regression analysis of the bacterial cell count was conducted for each time water type (marine versus fresh water), strain type (clinically versus environmental), organisms type (enterococci versus $E$. coli). The analysis revealed that the survival of all tested strains of enterococci and $E$. coli were significantly associated with the water type (fresh versus marine) $(\mathrm{p}=0.0004)$. On the whole, the population trends of $E$. coli and enterococci in fresh and marine water mesocosms did not reveal any evidence of growth. This is in line with the submission of a recent study in a tropical country setting with reported temperature of $29^{\circ} \mathrm{C}$ [24]. However this finding is contrary to the findings obtained in previous reports from subtropical environments in the US [25] [26]. The observation is also contrary to another study which reported that E. coli and E. faecium multiplied in autoclaved river water [27]. Comparison is difficult because this study was conducted using a temperature $\left(15^{\circ} \mathrm{C}\right)$ below the ambient temperatures in tropical locations while marine beach water was not included in the study design.

Our observations also revealed that saline water had a negative effect on the persistence of $E$. coli. This was highlighted as the decay rate of $E$. coli in marine water was higher than was observed for freshwater. For $E$. coli and all strains of enterococci tested, persistence appeared to be encouraged in sediments as bacteria cells were cultural two weeks after culturable bacteria was not detected in the water column. The average decay rate of enterococci strains from the clinical and epidemic strains was higher for fresh water than was observed for marine water indicating higher persistence of enterococi in marine water. This was also in agreement with the $T_{90}$ values with higher $\mathrm{T}_{90}$ values among clinical strains in marine water as compared to fresh water.

In a previous study, bacteria introduced in the culture medium remained culturable for more than three months at room temperature [15]. According to previous studies [15] [28] [29], during this period of nutrient limiting period, they may activate a survival or starvation mode to resume active division following the emergence of more favourable conditions. This was demonstrated in our recent report as starved cells resumed active growth after restoration of nutrients but produced biofilms at lower efficiency as compared to actively growing cells that were not subjected to starvation [24]. In our study, culturable bacteria were not detectable in samples from all fresh and marine water mesocosms beyond 23 days. There is no published information on a comparative assessment of the survival of epidemic and environmental strains of enterococci at a temperature of $29^{\circ} \mathrm{C} \pm$ $1^{\circ} \mathrm{C}$ which is common at tropical beaches all year round. As this temperature prevails in Malaysia and a number of countries in the Asian south east region, there is the need to assess location specific scenarios for the survival and persistence of faecal, commensal or clinical enterococci in available surface waters. This is particularly needed in Asia and similar tropical locations where surface water contamination present strong linkages with waterborne diseases [30].

In a recent study [24] that attempted to highlight an appropriate indicator organism for tropical beach water monitoring, enterococci concentrations negatively correlated with temperature as opposed to the positive correlation reported in some non-tropical countries. Ultraviolet radiations, light exposure in addition to temperature are important drivers of enterococci concentrations in tropical aquatic environments. The effect of ultraviolet radiation was however not tested in our study. Lleo et al. [15] reported that when cells in a mesocosm were left at room temperature in a non-tropical environment or at $4^{\circ} \mathrm{C}$ without direct light, they did not reach the non-culturable state but maintained their culturability for periods as long as two months indicating that they activated starvation instead of the VBNC (viable but not culturable) state. In tropical settings however, our findings suggest that a combination of tropical room temperature without direct light produced the non-culturable state after 20 days indicating that the activated the VBNC state rather than the starvation mode as was observed in the mesocosm study in a non-tropical setting reported by Lleo et al. [15].

While a range of temperature $\left(10^{\circ} \mathrm{C}-18^{\circ} \mathrm{C}\right)$ is recognised and reported as ambient temperatures for a number of studies that focused on the survival of indicator organisms in the environment, conditions in humid tropical settings may present different influence on population dynamics of microbes in these locations. Two fundamental issues thus arise: year round humid conditions and the high temperatures. Previous studies [21] [24] assert that temperature differences in tropical climates may influence the survival of indicator organisms in these environments. For instance, a study in Malaysia reported negative correlation of enterococci with temperature [23]. In another study, it took $10.97+3.47$ days to achieve 1-log reduction $\left(\mathrm{T}_{90}\right)$ for methicillin resistant Staphylococcus aureus strains in marine water kept at $13^{\circ} \mathrm{C}$. For a temperature higher by $7^{\circ} \mathrm{C}$, a $\mathrm{T}_{90}$ value of $7.89+1.62$ days was recorded. In Malaysia and neighbouring countries in the equator, a much higher ambient temperature of $29^{\circ} \mathrm{C}$ would undoubtedly exert its influence on the $T_{90}$ values. These are important considerations in the design of beach water quality surveillance programs. The second consideration for similar countries in the equator 
is that of all year round humid weather conditions prevalent in these locations. Arguably, more rainfall events in terms of frequency and intensity comes along with increased intensity and frequency of discharge of storm water run offs and combined sewer overflows (CSO) into recreational water available. Increased frequency and intensity of stormwater runoff in addition to pollution from diffuse sources may present a steady supply into recreational water of organic matter-rich nutrients along with non-indigenous faecal indicator organisms which nullifies the diminishing effect of temperature on indicator organism population dynamics in the tropics. This assumption however needs to be cautiously interpreted and validated in future studies particularly bearing in mind the differences in organic carbon constituent of the stormwater runoff in these tropical settings. Nonetheless, Anderson et al. [23] reported lowest decay rates (greatest persistence) in mesocosms inoculated with contaminated soil and waste water containing variable amounts of organic matter. Similar findings were reported by Fujioka and Unutoa [31] and Masmoudi et al. [32].

A limitation in the current study was the restriction of the variables tested to three viz: strain type, water type and organism type. The survival of bacteria in environmental waters is affected by a complex array of physical, chemical and biological factors that are often difficult to simulate in the laboratory [23] [33].

\section{Conclusion}

Our results show that epidemic, clinical, faecal and recreational beach enterococci strains containing putative virulent markers survived in marine and fresh waters for up to but not beyond 23 days in tropical temperatures $\left(29^{\circ} \mathrm{C}\right)$ while retaining their virulent markers for this period. Also, cells recovered from the sediment below the water column still retained their virulence markers. Potentially pathogenic bacteria can resume active growth after 3 weeks of being harboured by the reservoir-beach sand and still pose threat to public health.

\section{Acknowledgements}

Financial support for sampling and laboratory analysis from the Universiti Kebangsaan Malaysia Marine Pathogen Program Grant (Science Fund 04-01-02-SF0754) under the auspices of the School of Bioscience and Biotechnology, Faculty of Science and Technology is appreciated.

\section{References}

[1] Haller, L., Poté, J., Loizeau, J.-L. and Wildi, W. (2009) Distribution and Survival of Faecal Indicator Bacteria in the Sediments of the Bay of Vidy, Lake Geneva, Switzerland. Ecological Indicators, 9, 540-547. http://dx.doi.org/10.1016/j.ecolind.2008.08.001

[2] An, Y.-J., Kampbell, D.H. and Breidenbach, G.P. (2002) Escherichia coli and Total Coliforms in Water and Sediments at Lake Marinas. Environmental Pollution, 120, 771-778.

[3] Noble, R.T., Moore, D.F., Leecaster, M.K., McGee, C.D. and Weisberg, S.B. (2003) Comparison of Total Coliform, Fecal Coliform, and Enterococcus Bacterial Indicator Response for Ocean Recreational Water Quality Testing. Water Research, 37, 1637-1643. http://dx.doi.org/10.1016/S0043-1354(02)00496-7

[4] USEPA (2000) Improved Enumeration Methods for the Recreational Water Quality Indicators: Enterococci and Escherichia coli EPA-821/ R-97/004. U.S. Environmental Protection Agency, Washington DC.

[5] EU (2006) European Directive 2006/7/CE of the European Parliament and of the Council of 15 February 2006 Concerning the Management of Bathing Water Quality and Repealing, Directive 76/160/EEC.

[6] Shibata, T., Solo-Gabriele, H.M., Fleming, L.E. and Elmir, S. (2004) Monitoring Marine Recreational Water Quality Using Multiple Microbial Indicators in an Urban Tropical Environment. Water Research, 38, 3119-3131. http://dx.doi.org/10.1016/j.watres.2004.04.044

[7] Jett, B.D., Huycke, M.M. and Gilmore, M.S. (1994) Virulence of Enterococci. Clinical Microbiology Reviews, 7, 462478.

[8] Vergis, E.N., Shankar, N., Chow, J.W., Hayden, M.K., Snydman, D.R., Zervos, M.J., Linden, P.K., Wagener, M.M. and Muder, R.R. (2002) Association between the Presence of Enterococcal Virulence Factors Gelatinase, Hemolysin, and Enterococcal Surface Protein and Mortality among Patients with Bacteremia Due to Enterococcus faecalis. Clinical Infectious Diseases, 35, 570-575. http://dx.doi.org/10.1086/341977

[9] Semedo, T., Santos, M.A., Lopes, M.F., Marques, J.J.F., Crespo, M.T. and Tenreiro, R. (2003) Virulence Factors in Food, Clinical and Reference Enterococci: A Common Trait in the Genus? Systematic and Applied Microbiology, 26, 13-22. http://dx.doi.org/10.1078/072320203322337263 
[10] Dada, A.C., Ahmad, A., Usup, G. and Heng, L.Y. (2012) Antibiotic Resistance and Virulence Among Enterococci Isolated from Teluk Kemang Beach, Malaysia. Water Quality, Exposure and Health, 1-10.

[11] Facklam, R. and Elliott, J. (1995) Identification, Classification, and Clinical Relevance of Catalase-Negative, Gram-Positive Cocci, Excluding the Streptococci and Enterococci. Clinical Microbiology Reviews, 8, 479-495.

[12] Facklam, R. (2002) What Happened to the Streptococci: Overview of Taxonomic and Nomenclature Changes. Clinical Microbiology Reviews, 15, 613-630. http://dx.doi.org/10.1128/CMR.15.4.613-630.2002

[13] Dutka-Malen, S., Evers, S. and Courvalin, P. (1995) Detection of Glycopeptide Resistance Genotypes and Identification to the Species Level of Clinically Relevant Enterococci by PCR. Journal of Clinical Microbiology, 33, 24-27.

[14] Vankerckhoven, V., Van Autgaerden, T., Vael, C., Lammens, C., Chapelle, S., Rossi, R., Jabes, D. and Goossens, H. (2004) Development of a Multiplex PCR for the Detection of asa1, gelE, cylA, esp, and hyl Genes in Enterococci and Survey for Virulence Determinants among European Hospital Isolates of Enterococcus faecium. Journal of clinical microbiology, 42, 4473-4479. http://dx.doi.org/10.1128/JCM.42.10.4473-4479.2004

[15] Lleò, M.D.M., Bonato, B., Benedetti, D. and Canepari, P. (2005) Survival of Enterococcal Species in Aquatic Environments. FEMS Microbiology Ecology, 54, 189-196. http://dx.doi.org/10.1016/j.femsec.2005.03.016

[16] Halvorson, H. and Ziegler, N. (1933) Application of Statistics to Problems in Bacteriology: I. A Means of Determining Bacterial Population by the Dilution Method. Journal of Bacteriology, 25, 101-121.

[17] Giard, J.C., Laplace, J.M., Rincé, A., Pichereau, V., Benachour, A., Leboeuf, C., Flahaut, S., Auffray, Y. and Hartke, A. (2001) The Stress Proteome of Enterococcus faecalis. Electrophoresis, 22, 2947-2954.

[18] Liu, Y.F., Gao, X.J., Cong, Y.T., Peng, Y.H. and Liu, Y. (2004) Research on the Storage Methods of Lactic Acid Bacteria Strains Separated from DVS. Nature and Science, 2, 49.

[19] Iguchi, A., Osawa, R., Kawano, J., Shimizu, A., Terajima, J. and Watanabe, H. (2002) Effects of Repeated Subculturing and Prolonged Storage at Room Temperature of Enterohemorrhagic Escherichia coli O157: H7 on Pulsed-Field Gel Electrophoresis Profiles. Journal of Clinical Microbiology, 40, 3079-3081. http://dx.doi.org/10.1128/JCM.40.8.3079-3081.2002

[20] Tolba, O., Loughrey, A., Goldsmith, C.E., Millar, B.C., Rooney, P.J. and Moore, J.E. (2008) Survival of Epidemic Strains of Healthcare (HA-MRSA) and Community-Associated (CA-MRSA) Meticillin-Resistant Staphylococcus aureus (MRSA) in River-, Sea- and Swimming Pool Water. International Journal of Hygiene and Environmental Health, 211, 398-402. http://dx.doi.org/10.1016/j.ijheh.2007.06.003

[21] Levin-Edens, E., Bonilla, N., Meschke, J.S. and Roberts, M.C. (2011) Survival of Environmental and Clinical Strains of Methicillin-Resistant Staphylococcus aureus [MRSA] in Marine and Fresh Waters. Water Research, 45, 5681-5686. http://dx.doi.org/10.1016/j.watres.2011.08.037

[22] Shankar, V., Baghdayan, A.S., Huycke, M.M., Lindahl, G. and Gilmore, M.S. (1999) Infection-Derived Enterococcus faecalis Strains Are Enriched in Esp, a Gene Encoding a Novel Surface Protein. Infection and Immunity, 67, 193-200.

[23] Anderson, K.L., Whitlock, J.E. and Harwood, V.J. (2005) Persistence and Differential Survival of Fecal Indicator Bacteria in Subtropical Waters and Sediments. Applied and Environmental Microbiology, 71, 3041-3048. http://dx.doi.org/10.1128/AEM.71.6.3041-3048.2005

[24] Ahmad, A., Dada, A.C., Usup, G. and Heng, L.Y. (2013) Validation of the Enterococci Indicator for Bacteriological Quality Monitoring of Beaches in Malaysia Using a Multivariate Approach. SpringerPlus, 2, 425.

[25] Desmarais, T.R., Solo-Gabriele, H.M. and Palmer, C.J. (2002) Influence of Soil on Fecal Indicator Organisms in a Tidally Influenced Subtropical Environment. Applied and Environmental Microbiology, 68, 1165-1172. http://dx.doi.org/10.1128/AEM.68.3.1165-1172.2002

[26] Solo-Gabriele, H.M., Wolfert, M.A., Desmarais, T.R. and Palmer, C.J. (2000) Sources of Escherichia coli in a Coastal Subtropical Environment. Applied and Environmental Microbiology, 66, 230-237. http://dx.doi.org/10.1128/AEM.66.1.230-237.2000

[27] Medema, G., Bahar, M. and Schets, F. (1997) Survival of Cryptosporidium parvum, Escherichia coli, Faecal Enterococci and Clostridium perfringens in River Water: Influence of Temperature and Autochthonous Microorganisms. Water Science and Technology, 35, 249-252. http://dx.doi.org/10.1016/S0273-1223(97)00267-9

[28] Lleo, M., Bonato, B., Tafi, M., Signoretto, C., Boaretti, M. and Canepari, P. (2001) Resuscitation Rate in Different Enterococcal Species in the Viable but Non-Culturable State. Journal of Applied Microbiology, 91, 1095-1102. http://dx.doi.org/10.1046/j.1365-2672.2001.01476.x

[29] del Mar Lleo, M., Tafi, M.C. and Canepari, P. (1998) Nonculturable Enterococcus faecalis Cells Are Metabolically Active and Capable of Resuming Active Growth. Systematic and Applied Microbiology, 21, 333-339. http://dx.doi.org/10.1016/S0723-2020(98)80041-6

[30] Isobe, K.O., Tarao, M., Chiem, N.H., Minh, L.Y. and Takada, H. (2004) Effect of Environmental Factors on the Rela- 
tionship between Concentrations of Coprostanol and Fecal Indicator Bacteria in Tropical (Mekong Delta) and Temperate (Tokyo) Freshwaters. Applied and Environmental Microbiology, 70, 814-821.

http://dx.doi.org/10.1128/AEM.70.2.814-821.2004

[31] Fujioka, R. and Unutoa, T. (2006) Comparative Stability and Growth Requirements of S. aureus and Faecal Indicator Bacteria in Seawater. Water Science and Technology, 54, 169-175. http://dx.doi.org/10.2166/wst.2006.465

[32] Masmoudi, S., Denis, M. and Maalej, S. (2010) Inactivation of the Gene katA or sodA affects the Transient Entry into the Viable but Non-Culturable Response of Staphylococcus aureus in Natural Seawater at low Temperature. Marine Pollution Bulletin, 60, 2209-2214. http://dx.doi.org/10.1016/j.marpolbul.2010.08.017

[33] McFeters, G.A. and Terzieva, S.I. (1991) Survival of Escherichia coli and Yersinia enterocolitica in Stream Water: Comparison of Field and Laboratory Exposure. Microbial Ecology, 22, 65-74. http://dx.doi.org/10.1007/BF02540213 